\title{
AKTY PRAWA MIEJSCOWEGO Z ZAKRESU OCHRONY POWIETRZA W ŚWIETLE WYBRANEGO ORZECZNICTWA SĄDÓW ADMINISTRACYJNYCH
}

\section{LOCAL LEGISLATION ON THE PROTECTION OF AMBIENT AIR IN THE LIGHT OF ADMINISTRATIVE COURTS CASE-LAW}

\section{STRESZCZENIE}

Zgodnie z zasadą decentralizacji władzy publicznej ochrona powietrza w Polsce jest realizowana również na szczeblu samorządu terytorialnego. Zagadnienia ochrony powietrza w sposób całościowy regulowane są w Ustawie Prawo ochrony środowiska i tam też należy szukać delegacji ustawowych do wykonywania przez samorząd tery-

* Magister prawa, doktorantka w Instytucie Nauk Prawnych PAN. 
torialny zadań w tym zakresie. Na tej podstawie sejmiki wojewódzkie mają kompetencję do uchwalania programów ochrony powietrza, planów działań krótkoterminowych oraz podejmowania uchwał w celu zapobieżenia negatywnemu oddziaływaniu na środowisko lub na zabytki. Działalność samorządów w tym zakresie podlega kontroli sądów administracyjnych, które - niejednokrotnie uwzględniając skargi na rzeczone uchwały - wypowiadają krytyczne uwagi na temat jakości tej legislacji. Niniejszy artykuł stanowi próbę przedstawienia wymagań, jakim powinny odpowiadać akty prawa miejscowego w zakresie ochrony powietrza oraz identyfikacji przyczyn ich wadliwości.

\section{Słowa kluczowe}

Ochrona powietrza; akt prawa miejscowego; program ochrony powietrza; plan działań krótkoterminowych.

\section{ABSTRACT}

According to the principle of decentralization of public authority, the protection of ambient air in Poland is executed also on the selfgovernmental level. The complex regulation of the issues concerning the protection of ambient air is included in the Act on Environmental Protection Law where the competence to adopt local acts is given to self-governmental authorities. On that ground, the voivodeship assemblies may propose resolutions such as air-protection programmes, short-term activities plans and those preventing the negative impact on the environment or historical monuments. The activity of local selfgovernment within this scope is subject to the control of administrative courts, which often take the submitted complaints into consideration and criticize the quality of the local legislation. This article will thus attempt to present the requirements that shall be fulfilled by the local acts on ambient air protection and identify the sources of their most frequent imperfections.

\section{Keywords}

Ambient air protection; local self-government act; air protection programme; short-activity plan. 


\section{WSTĘP}

Na wstępie wypada zastanowić się nad pojęciem aktów prawa miejscowego $\mathrm{i}$ ich usytuowaniem $\mathrm{w}$ polskim systemie prawnym. Akty prawa miejscowego są, zgodnie z art. 87 ust. 2 Konstytucji Rzeczypospolitej Polskiej z dnia 2 kwietnia 1997 r. ${ }^{1}$, źródłami powszechnie obowiązującego prawa na obszarze działania organów, które je ustanowiły. Zasady tworzenia prawa miejscowego zostały ujęte w Konstytucji dość lakonicznie ${ }^{2}$. W art. 94 Konstytucji wskazane zostały w sposób rodzajowy organy upoważnione do stanowienia aktów prawa miejscowego, tj. organy samorządu terytorialnego oraz terenowe organy administracji rządowej. Ponadto art. 94 Konstytucji stanowi, iż akty prawa miejscowego mogą być stanowione tylko „na podstawie i w granicach upoważnień zawartych w ustawie", przy czym chodzi zarówno o tzw. samorządowe ustawy ustrojowe, tj. Ustawę z dnia 8 marca 1990 r. o samorządzie gminnym ${ }^{3}$, Ustawę z dnia 5 czerwca 1998 r. o samorządzie powiatowym ${ }^{4}$ i Ustawę z dnia 5 czerwca 1998 r. o samorządzie województwa $^{5}$, jak i delegacje zawarte w ustawach materialnego prawa administracyjnego, w szczególności w Ustawie z dnia 27 kwietnia 2001 r. Prawo ochrony środowiska ${ }^{6}$.

Upoważnienie ustawowe do wydania aktu prawa miejscowego powinno być wyraźne, a nie domniemane. Powinno wskazywać organ mający kompetencję do wydania danego aktu, jak też zakres przyszłej regulacji. W tym jednak aspekcie należy zwrócić uwagę na demokratyczną legitymację organów samorządu terytorialnego powołanych do stanowienia prawa miejscowego, co powinno przemawiać przeciw zawężającej

1 Dz.U. nr 78, poz. 483 ze zm., dalej cyt.: Konstytucja.

2 W. Skrzydło, Konstytucja Rzeczypospolitej Polskiej. Komentarz, Warszawa 2013, s. 113

3 T.j. Dz.U. z 2013 r., poz. 594 ze zm.

4 T.j. Dz.U. z 2013 r., poz. 595 ze zm.

5 T.j. Dz.U. z 2013 r., poz. 596 ze zm.

6 T.j. Dz.U. z 2013 r., poz. 1232 ze zm., dalej cyt.: u.p.o.ś. 
wykładni ich kompetencji prawodawczych ${ }^{7}$. W rezultacie upoważnienie do wydania aktu prawa miejscowego nie powinno być nadmiernie szczegółowe - powinno ograniczać się jedynie do wskazania organu upoważnionego, do wydania aktu oraz przedmiotu regulacji.

Istotne ograniczenia, co do zakresu i stopnia samodzielności organów samorządu terytorialnego na płaszczyźnie treści stanowionych norm $^{8}$, narzuca jednak sama ustawa zasadnicza, stawiając akty prawa miejscowego na ostatnim miejscu w konstytucyjnej hierarchii źródeł prawa ${ }^{9}$. Akty prawa miejscowego muszą być zgodne z Konstytucją, ratyfikowanymi umowami międzynarodowymi, ustawami oraz rozporządzeniami, co oznacza, że kompetencje prawotwórcze samorządów mają w rzeczywistości charakter wtórny i wykonawczy.

\section{POWSZECHNIE OBOWIĄZUJĄCY CHARAKTER AKTÓW PRAWA MIEJSCOWEGO}

Nie wszystkie akty prawne organów stanowiących jednostek samorządu terytorialnego są aktami prawa miejscowego. Rozróżnienie uchwał tych organów na akty prawa miejscowego i akty nimi niebędącymi jest istotne, gdyż tylko te pierwsze mają cechę powszechnego obowiązywania na obszarze działania organów, które je ustanowiły. Powszechny charakter tych aktów

7 I. Chojnacka, Przesłanki legalności aktu prawa miejscowego $w$ orzecznictwie sądów administracyjnych, „Zeszyty Naukowe Sądownictwa Administracyjnego" 2012, nr 4, s. 45.

8 A. Wiktorowska, Prawne determinanty samodzielności gminy (zagadnienia administracyjno-prawne), Warszawa 2002, s. 57; B. Dolnicki, Akty prawa miejscowego samorządu terytorialnego, "Samorząd Terytorialny” 2004, nr 5, s. 9-10; M. Kamiński, Koncepcja nieważności aktów prawa miejscowego jednostek samorzadu terytorialnego $w$ polskich ustawach samorządowych, „Samorząd Terytorialny" 2007, nr 5, s. 50.

9 Z. Bukowski, Możliwości prawne wprowadzenia zakazu spalania określonych paliw stałych na terenie gminy, „Studia z zakresu prawa, administracji i zarządzania UKW" 2012, t. 1, s. 50. 
oznacza bowiem, że ich adresatem mogą być wszystkie podmioty przebywające na terenie działania danego organu. Dla odróżnienia - akty kierownictwa wewnętrznego, również należąc do kategorii aktów normatywnych, obowiązują tylko w stosunku do jednostek organizacyjnie podległych autorowi takiego aktu ${ }^{10}$.

W upoważnieniu ustawowym do wydania aktu prawa miejscowego określony jest organ kompetentny do jego wydania, przedmiot regulacji i forma aktu (np. uchwała). Nie zawsze jednak ustawodawca wskazuje expressis verbis, że wydany na podstawie upoważnienia akt jest aktem prawa miejscowego. W doktrynie i orzecznictwie przyjmuje się, że, jeśli ustawa nie określa wprost, że dany akt lokalnego legislatora jest lub nie jest aktem prawa miejscowego, to konieczne jest ustalenie jego przymiotu prawotwórczego w drodze analizy jego cech materialnych i formalnych ${ }^{11}$.

Akty prawa miejscowego, jako źródła prawa powszechnie obowiązującego, powinny być aktami normatywnymi, czyli powinny zawierać wypowiedzi dyrektywne wyznaczające adresatom pewien sposób zachowania się: mogą to być nakazy, zakazy lub uprawnienia ${ }^{12}$. Ponadto powinny spełniać wymogi stawiane $\mathrm{w}$ teorii prawa aktom tworzenia prawa, czyli aktom normatywnym, w których zawarte są normy prawne o charakterze ogólnym ${ }^{13}$. Ogólność norm prawnych wyraża się w dwóch cechach: abstrakcyjności i generalności. Charakter generalny mają te normy, które określają adresata poprzez wskazanie cech, a więc przy użyciu nazwy generalnej, nie zaś poprzez wymienienie $\mathrm{z}$ imienia lub nazwy (rodzajowe oznaczenie adresata). Natomiast abstrakcyjność normy prawnej wyraża się w tym, że

10 W. Federczyk, B. Majchrzak, Akt normatywny w orzecznictwie Trybunału Konstytucyjnego. Problemy na tle aktów organów administracji, w: Źródła prawa administracyjnego a ochrona wolności i praw obywateli, red. M. Błachucki, T. Górzyńska, Warszawa 2014, s. 166.

11 J. Ciapała, Powszechnie obowiązujące akty prawa miejscowego, „Przegląd Sejmowy” 2000, nr 3, s. 34 i n.; T. Szewc, Problem kwalifikacji aktów prawa miejscowego, „Przegląd Sejmowy” 2006, nr 3, s. 52.

12 D. Dąbek, Prawo miejscowe, Kraków-Bydgoszcz 2007, s. 74; Z. Ziembiński, Teoria prawa, Warszawa-Poznań 1977, s. 22.

13 L. Morawski, Wstęp do prawoznawstwa, Toruń 2014, s. 55. 
nakazywane, zakazywane czy dozwolone zachowanie ma mieć miejsce $\mathrm{w}$ pewnych, $\mathrm{z}$ reguły powtarzalnych, okolicznościach, nie zaś w jednej konkretnej sytuacji. Akty prawa miejscowego mają zatem charakter powtarzalny, nie mogą bowiem konsumować się poprzez jednorazowe zastosowanie ${ }^{14}$. Należy przy tym zwrócić uwagę, że kazuistyczność normy prawnej, tzn. określenie w sposób szczegółowy - wręcz drobiazgowy - wzoru zachowania, dopóki możliwe jest wielokrotne spełnienie tego wzoru przez adresatów, w dalszym ciągu nie wyklucza uznania danej normy za abstrakcyjną. Nie jest to jednak zalecane w technice legislacyjnej, gdyż „stwarza niebezpieczeństwo niezamierzonego pozostawienia poza sferą unormowania stanów rzeczy nie wymienionych w przepisach prawnych"15.

Co do zasady, obecność w danej uchwale organu stanowiącego jednostki samorządu terytorialnego normy prawnej o charakterze indywidualnym będzie prowadziło do nieuznania jej za akt prawa miejscowego. Normy indywidualno-konkretne są bowiem aktami stosowania, a nie stanowienia prawa. Jednak, jak zauważa L. Morawski, „granica między tworzeniem i stosowaniem prawa nie jest tak ostra [...], w wielu aktach normatywnych, które niewątpliwie zaliczane są do aktów tworzenia prawa spotykamy się niekiedy $\mathrm{z}$ normami indywidualnymi lub konkretnymi"16. Podobnie stwierdza J. Zimmermann, iż ustawodawca przestał mieścić się w klasycznych podziałach i stanowi dla administracji publicznej formy działania łamiące nieraz utarte kryteria klasyfikacji ${ }^{17}$. Przedstawiany jest również pogląd o nietrafności dychotomicznego podziału na normy generalno-abstrakcyjne albo normy indywidualno-konkretne ${ }^{18}$.

14 L. Morawski, op. cit., s. 48; D. Dąbek, op. cit., s. 75; S. Dudziak, Akty prawa miejscowego stanowione przez samorząd terytorialny - kryteria kwalifikacji, wymogi $w$ zakresie prawidłowego stanowienia oraz konsekwencje prawne ich naruszenia, „Samorząd Terytorialny” 2012, nr 3, s. 9.

15 T. Stawecki, P. Winczorek, Wstęp do prawoznawstwa, Warszawa 2003, s. 64.

16 L. Morawski, Wstęp do prawoznawstwa, Toruń 1997, s. 79.

17 J. Zimmermann, Prawo administracyjne, Warszawa 2008, s. 283.

18 E. Frankiewicz, M. Szewczyk, Generalny akt administracyjny, „Państwo i Prawo" 2003, nr 12, s. 43. 
Niezależnie od tych konstatacji, przypadki pojawiania się w treści aktów normatywnych reguł konkretnych lub indywidualnych powinny być traktowane jako wyjątki. Normy prawne powinny bowiem, ze względu na swą użyteczność społeczną, a także, co warto podkreślić - bezpieczeństwo prawne jednostki - powinno znajdować wielokrotne zastosowanie ${ }^{19}$.

W świetle powyższego $\mathrm{w}$ przypadku danego aktu prawa miejscowego niezbędne jest każdorazowe ustalenie, czy dany akt spełnia podstawowe kryteria pozwalające na zaliczenie go do kategorii aktów tworzenia prawa. Kwestią wyznaczenia tych kryteriów zajął się również Trybunał Konstytucyjny, gdyż pojęcie aktu normatywnego stanowi główny wyznacznik zakresu jego kognicji. Trybunał Konstytucyjny wypracował tzw. doktrynę aktu normatywnego, wedle której rozstrzygające znaczenie, co do konkretnej oceny normatywności aktu, ma treść, a nie jego forma czy nazwa ${ }^{20}$. Zauważył także, iż „wątpliwości co do normatywnego charakteru niektórych aktów prawnych wydają się być nieodłączną cechą systemu prawnego"21. Problematyczna jest zwłaszcza kwestia rozróżnienia aktów prawa miejscowego od aktów prawa wewnętrznego, która wskazywana jest w literaturze jako częsty przedmiot sporów w orzecznictwie sądów administracyjnych ${ }^{22}$. W orzecznictwie sądów administracyjnych ugruntował się pogląd, że do uznania uchwały za akt prawa miejscowego wystarczy, jeśli zawiera ona przynajmniej jedną normę postępowania o charakterze generalnym i abstrakcyjnym $^{23}$. Pojawiają się także i takie głosy w dyskusji, że do stwierdzenia powszechnej mocy wiążącej przepisu wystarczające jest, aby był on bądź generalny, bądź abstrakcyjny ${ }^{24}$, gdyż

19 T. Stawecki, P. Winczorek, op. cit., s. 65.

20 W. Federczyk, B. Majchrzak, op. cit., s.153-154.

21 Wyrok Trybunału Konstytucyjnego z dnia 12 lipca 2001 r., SK 1/01.

22 Z. Bukowski, T. Jędrzejewski, P. Rączka, Ustrój samorządu terytorialnego, Toruń 2011, s. 105.

23 Np. Wyrok Naczelnego Sądu Administracyjnego z dnia 18 lipca 2006 r., I OSK 669/06.

24 T. Szewc, op. cit., s. 52; P. Dobosz, Quasi-akty prawa miejscowego, w: Problemy prawne działalności samorządu terytorialnego, red. S. Dolata, Opole 2002, s. 135. 
zdarzają się sytuacje, w których akt prawny nie jest zarazem abstrakcyjny i generalny, a pomimo to posiada powszechną moc obowiązującą. Wydaje się jednak, że należy to traktować jako wyjątek od reguły, przy czym dalsze rozważania w tym zakresie wykraczają poza ramy niniejszego opracowania.

Podsumowując, powszechnie obowiązujące akty prawa miejscowego to akty normatywne (zasadniczo o charakterze generalnym i abstrakcyjnym), stanowione przez określone w ustawach organy administracji publicznej (samorządowej i rządowej) oraz obowiązujące na obszarze państwa odpowiadającym obszarowi działania organu, który je ustanowił ${ }^{25}$. Konsekwencją zaliczenia aktu do kategorii aktów prawa miejscowego jest formalny obowiązek ich publikacji w wojewódzkich dziennikach urzędowych. Wynika to wprost z art. 13 ust. 1 Ustawy z dnia 20 lipca 2000 r. o ogłaszaniu aktów normatywnych i niektórych innych aktów prawnych ${ }^{26}$.

Akty prawa miejscowego, jako źródła prawa powszechnie obowiązującego na obszarze działania organów, które je ustanowiły, podlegają kontroli sądów administracyjnych. Kryterium kontroli jest legalność aktu, tzn. istnienie ustawowego upoważnienia do wydania aktu, kompetencja organu do wydania aktu, zgodność regulowanych w akcie prawa miejscowego materii z postanowieniami Konstytucji i ustaw ${ }^{27}$. Można również wskazać rodzaje naruszeń prawa, które są podstawą wadliwości aktów prawa miejscowego. Do tego rodzaju naruszeń należy zaliczyć: naruszenie przepisów wyznaczających kompetencje do podejmowania aktów prawa miejscowego, brak podstaw prawnych do podjęcia aktu prawa miejscowego, naruszenie przepisów prawa materialnego regulujących podstawy podjęcia aktu prawa miejscowego oraz przepisów regulujących procedurę podjęcia aktu prawa miejscowego. Ustawa z dnia 30 sierpnia

25 M. Kotulski, Akty prawa miejscowego w świetle uregulowań ustrojowych, „Kwartalnik Prawa Publicznego” 2001, nr 1, s. 57; T. Jaroszyński, Zasady techniki prawodawczej a akty prawa miejscowego. Wybrane problemy $w$ świetle orzecznictwa Naczelnego Sądu Administracyjnego, „Kwartalnik Prawa Publicznego" 2013, nr 1, s. 134.

26 T.j. Dz.U. z 2011 r., poz. 1172 ze zm.

27 I. Chojnacka, op. cit., s. 40. 
2002 r. Prawo o postępowaniu przed sądami administracyjny$\mathrm{mi}^{28}$, w odniesieniu do wadliwych aktów prawa miejscowego, wprowadza w art. $147 \S 1$ jednego rodzaju sankcję: sankcję nieważności aktu w całości lub w części ${ }^{29}$, przy czym wyrok stwierdzający nieważność aktu ma charakter deklaratoryjny i wywiera skutki ex tunc. Akt prawa miejscowego sprzeczny z prawem nawet w stopniu oczywistym zachowuje moc obowiązującą aż do daty jego autorytatywnego uchylenia przez sąd administracyjny $^{30}$.

\section{AKTY PRAWA MIEJSCOWEGO W ZAKRESIE OCHRONY POWIETRZA}

Zagadnienia ochrony jakości powietrza w sposób całościowy regulowane są w u.p.o.ś. ${ }^{31}$ i tam też należy szukać delegacji ustawowych do wydania aktów prawa miejscowego $\mathrm{w}$ tym zakresie. Kompetencje takie zostały przyznane organom samorządu terytorialnego na poziomie województwa, mianowicie sejmik województwa podejmuje następujące uchwały: 1) „programy ochrony powietrza” - na podstawie art. 91 ust. 3 w związku z art. 84 ust. 1 u.p.o.ś. i 2) „plany działań krótkoterminowych" - na podstawie art. 92 ust. 1c w związku z art. 84 ust. 1 u.p.o.ś., przy czym oba rodzaje tych aktów nazywane są w doktrynie „programami naprawczymi” oraz 3) tzw. uchwały antysmogowe - podejmowane w celu zapobieżenia negatywnemu oddziaływaniu na środowisko lub na zabytki na podstawie art. 96 u.p.o.ś.

Jak wynika z analizy językowej przepisów, programy naprawcze są uchwalane obligatoryjnie w przypadku wystąpienia

28 T.j. Dz.U. z 2012 r., poz. 270 ze zm., dalej cyt.: u.p.p.s.a.

29 B. Adamiak, Nieważność aktu prawa miejscowego a wadliwość decyzji administracyjnej, „Państwo i Prawo” 2002, nr 9, s. 17.

30 M. Kamiński, op. cit., s. 57.

31 M. Górski, Prawo ochrony środowiska, red. M. Górski, Warszawa 2014, s. 234. 
określonych w ustawie przesłanek ${ }^{32}$, podczas gdy „uchwała antysmogowa" pozostaje fakultatywnym instrumentem ochrony powietrza przed zanieczyszczeniami. W przypadku programów naprawczych można by się zatem zastanawiać nad możliwością wniesienia skargi na niewykonanie czynności nakazanych prawem przez niepodjęcie aktu prawa miejscowego w określonym ustawą terminie, jednak takie stanowisko byłoby sprzeczne $\mathrm{z}$ regulacją zawartą $\mathrm{w}$ art. $3 \S 2$ pkt 8 u.p.p.s.a., w którym ustawodawca wyraźnie zrezygnował z kontroli bezczynności prawodawczej organów samorządu terytorialnego i terenowych organów administracji rządowej przez sądy administracyjne ${ }^{33}$.

W polskim prawie ochrony środowiska występuje rozdzielenie kompetencji w zakresie monitoringu zanieczyszczeń, a więc oceny i diagnozy sytuacji wymagającej interwencji legislacyjnej i kompetencji w zakresie opracowania programów naprawczych. Badania monitoringowe są bowiem prowadzone przez organy merytoryczne wchodzące w skład wojewódzkiej administracji zespolonej, tj. wojewódzkich inspektorów ochrony środowiska, którzy zadania te wykonują z pomocą wojewódzkich inspektoratów ochrony środowiska. Z kolei odnośnie kompetencji legislacyjnej, należy wskazać, że zarząd województwa wszczyna stosowną procedurę, jednak formalnie nie ma żadnego wpływu na radnych sejmiku, by dany program został przez nich przyjęty w pożądanym kształcie. Taki rozdział kompetencji może rodzić opóźnienia w podejmowaniu działań, do których organy te są zobowiązane na mocy ustawy oraz wywołuje obawy, iż to względy pozamerytoryczne mogą decydować o treści programów. W związku z tym w doktrynie pojawiają się postu-

32 Art. 91 ust. 1 u.p.o.ś.: „dla stref [...] zarząd województwa opracowuje i przedstawia [...] projekt uchwały w sprawie programu ochrony powietrza” oraz art. 91 ust. 3 u.p.o.ś.: „sejmik województwa [...] określa, w drodze uchwały, program ochrony powietrza".

33 M. Stahl, Zagadnienia proceduralne sądowej kontroli aktów prawa miejscowego, „Zeszyty Naukowe Sądownictwa Administracyjnego” 2013, nr 3, s. 67. 
laty reformy instytucjonalno-organizacyjnej w zakresie ochrony powietrza $^{34}$.

\subsection{PROGRAM NAPRAWCZY}

Programy tworzone na podstawie art. 84 u.p.o.ś. zwane są w doktrynie "programami naprawczymi”"35, co nawiązuje do ich restytucyjnej funkcji w ochronie środowiska. Są one bowiem stanowione w sytuacji przekroczenia standardów jakości środowiska, w celu doprowadzenia do ich przestrzegania.

Przepis art. 84 u.p.o.ś. wyraźnie wskazuje, że program naprawczy tworzony jest w drodze aktu prawa miejscowego. Jednak upoważnienie ustawowe zawarte w art. 84 u.p.o.ś. zostało sformułowane w specyficzny sposób, gdyż ustawodawca wymaga dodatkowej podstawy prawnej zawartej w przepisach szczególnych: u.p.o.ś. lub innych ustaw. W konsekwencji organ, niezależnie od art. 84 u.p.o.ś., musi powołać także dodatkowo inną podstawę $\mathrm{w}$ przepisie szczególnym ${ }^{36}$. Powszechnie obowiązujący charakter prawny programu naprawczego wymaga, by zawierał on normy o charakterze generalnym i abstrakcyjnym ${ }^{37}$. Tym samym należy odróżniać programy tworzone w oparciu o art. 84 u.p.o.ś. od wojewódzkich, powiatowych

34 K. Karpus, Implementation of directive 2008/50/EC of 21 May 2008 on Ambient Air Quality and Cleaner Air for Europe in Polish environmental law, „Polish Yearbook of Environmental Law” 2012, s. 63. W podobnym duchu, zwłaszcza odnośnie połączenia w jednym organie na kształt agencji ochrony środowiska kompetencji technicznych i prawnych, wypowiada się G. Dobrowolski, Propozycja reformy instytucjonalnej ochrony środowiska, w: Administracja publiczna - człowiek a ochrona środowiska. Zagadnienia społeczno-prawne, red. M. Górski, J. Bucińska, M. Niedziółka, R. Stec, D. Strus, Warszawa 2011, s. 102-103.

35 M. Pchałek, w: M. Górski, M. Pchałek, W. Radecki, J. Jerzmański, M. Bar, S. Urban, J. Jendrośka, Prawo ochrony środowiska. Komentarz, Warszawa 2014, s. 229; P. Korzeniowski, Model prawny ochrony powietrza w ustawie Prawo ochrony środowiska, „Prawo i Środowisko” 2014, nr 1, s. 107.

36 B. Rakoczy, w: Z. Bukowski, E. K. Czech, K. Karpus, B. Rakoczy, Prawo ochrony środowiska. Komentarz, Warszawa 2013, s. 126.

37 Choć z samego upoważnienia ustawowego zawartego w art. 84 ust. 2 pkt 6 lit. c u.p.o.ś. wynika, że w tym przypadku program naprawczy może 
i gminnych programów ochrony środowiska, o których mowa w art. 17 u.p.o.ś. ${ }^{38}$ Te ostatnie zawierają bowiem wyłącznie niewiążące normy planistyczne i kwalifikuje się je jako tzw. akty oddziaływania, które mają jedynie stymulować podmioty oddziałujące na środowisko do podejmowania określonych działań i nie są źródłami prawa powszechnie obowiązującego w rozumieniu art. 87 Konstytucji ${ }^{39}$.

Powyższe nie oznacza, że same programy naprawcze nie są aktami planowania administracji - owszem, są nimi ze względu na swój cel i treść, jednak wolą ustawodawcy przybierają formę aktu prawa miejscowego ${ }^{40}$. O realizowaniu przez program naprawczy funkcji planistycznej świadczą elementy, jakie muszą się w nim znaleźć zgodnie z art. 84 ust. 2 u.p.o.ś.: oprócz obszaru objętego zakresem obowiązywania programu mają być w nim wskazane naruszone standardy jakości środowiska wraz z podaniem zakresu naruszenia, podstawowe kierunki i zakres działań niezbędnych do przywracania standardów jakości środowiska, harmonogram rzeczowo-finansowy planowanych działań, podmioty, do których skierowane są obowiązki ustalone $\mathrm{w}$ programie, $\mathrm{w}$ razie potrzeby dodatkowe obowiązki podmiotów korzystających ze środowiska, związane z ograniczaniem oddziaływania na środowisko, polegające na: 1) obowiązku prowadzenia pomiarów wielkości emisji lub poziomów

zawierać normy skierowane do adresata lub adresatów indywidualnie oznaczonych (w zakresie ograniczenia czasu obowiązywania pozwolenia).

38 Por. WSA w Łodzi w Wyroku z dnia 14 marca 2012 r., II SA/Łd 99/12: „zgodnie z przepisami Ustawy Prawo ochrony środowiska »programy ochrony środowiska« mają realizować politykę ekologiczną państwa (art. 17 ust. 1 u.p.o.ś.) ich treść ma znaczenie kierunkowe, nie konkretyzujące jeszcze uprawnień lub obowiązków podmiotów zewnętrznych. Dopiero odrębnie nazwane przez ustawodawcę »programy« (bez określenia ochrony środowiska), o jakim mowa w art. 84 u.p.o.ś. mogą zawierać regulacje powszechnie obowiązujące, gdyż ich celem jest doprowadzenie do przestrzegania standardów jakości ochrony środowiska przez wszystkie podmioty".

39 K. Gruszecki, Komentarz do art. 17 u.p.o.ś., w: Prawo ochrony środowiska. Komentarz, Warszawa 2011, LEX 2011.

40 R. Stankiewicz, Znaczenie aktów planowania $w$ prawie ochrony środowiska, w: Źródła prawa administracyjnego a ochrona wolności i praw obywateli, red. M. Błachucki, T. Górzyńska, Warszawa 2014, s. 189-190. 
substancji lub energii w środowisku; 2) obowiązku przekazywania, ze wskazaną częstotliwością, wyników prowadzonych pomiarów oraz informacji dotyczących przestrzegania wymagań określonych w posiadanych pozwoleniach; 3) ograniczeniu czasu obowiązywania posiadanych przez dany podmiot pozwoleń, nie krócej jednak niż do 2 lat, jak również obowiązki organów administracji, polegające na przekazywaniu organowi przyjmującemu program informacji o wydawanych decyzjach mających wpływ na realizację programu oraz sposób kontrol, dokumentowania realizacji programu i jego efektów.

Programy naprawcze wiążą, jako akty prawa miejscowego, nie tylko organy administracji publicznej, ale również inne podmioty. Uważa się, że możliwość nałożenia dodatkowych obowiązków w stosunku do tych określonych w u.p.o.ś., pozwoleniach emisyjnych oraz innych decyzjach administracyjnych jest ograniczona do obowiązków pomiarowych i informacyjnych, w szczególności harmonogram rzeczowo-finansowy nie może konstruować obowiązków (zwłaszcza finansowych) dla podmiotów niepodporządkowanych ${ }^{41}$, co nie zmienia stanu rzeczy, że obowiązki innych podmiotów mogą wynikać bezpośrednio z rozwiązań zawartych $\mathrm{w}$ programach naprawczych ${ }^{42}$. Należy zauważyć, że nakładanie obowiązku w konkretnej sytuacji dokonywane jest w drodze aktu normatywnego, a nie w drodze decyzji administracyjnej ${ }^{43}$. W praktyce może rodzić to istotne problemy dla lokalnych organów stanowiących. Podstawowym błędem przez nie popełnianym, być może ze względu na niezrozumienie tej specyficznej konstrukcji, jest umieszczanie w programach naprawczych norm konkretnych i indywidualnych, co skutkuje stwierdzaniem przez sądy administracyjne nieważności tych aktów. Przykłady takich orzeczeń znajdują się w dalszej części opracowania.

41 M. Górski, w: Ustawa - Prawo ochrony środowiska, red. J. Jendrośka, Wrocław 2005, s. 355.

42 K. Gruszecki, Komentarz do art. 84 u.p.o.ś, op.cit.

43 B. Rakoczy, op. cit., s. 127; Zgodnie z innym poglądem źródłem obowiązków tych podmiotów będą najczęściej indywidualne akty administracyjne uwzględniające rozwiązania wynikające z programów. J. Rotko, Komentarze do ustawy - Prawo ochrony środowiska, Wrocław 2002, s. 84. 


\subsection{PROGRAM OCHRONY POWIETRZA}

Programy ochrony powietrza są programami naprawczymi w rozumieniu art. 84 u.p.o.ś., zaliczanymi do instrumentów zarządzania jakością powietrza. Mają one na celu osiągnięcie poziomów dopuszczalnych substancji $\mathrm{w}$ powietrzu oraz pułapu stężenia ekspozycji. Procedurę tworzenia programów ochrony powietrza reguluje art. 91 u.p.o.ś., który stanowi implementację art. 23 Dyrektywy Parlamentu Europejskiego i Rady nr 2008/50/WE z dnia 21 maja 2008 r. w sprawie jakości powietrza i czystszego powietrza dla Europy ${ }^{44}$, zobowiązującego państwa członkowskie do zapewnienia sporządzenia planów ochrony powietrza dla tych stref i aglomeracji, w których poziomy zawartości zanieczyszczeń w powietrzu jednej lub kilku substancji przekraczają wartości dopuszczalne lub wartości docelowe, powiększone o odpowiednie marginesy tolerancji.

Trudno nie zwrócić uwagi na długie terminy, które ustawodawca przewidział dla uchwalenia programu ochrony powietrza. Mianowicie, po otrzymaniu od wojewódzkiego inspektora ochrony środowiska informacji o przekroczeniu przez szkodliwe substancje poziomu dopuszczalnego powiększonego o margines tolerancji, zarząd województwa ma aż 15 miesięcy, od dnia otrzymania wyników oceny poziomów substancji w powietrzu i klasyfikacji stref, na opracowanie i przedstawienie do zaopiniowania właściwym wójtom, burmistrzom lub prezydentom miast oraz starostom projektu Uchwały w sprawie programu ochrony powietrza. Dotyczy to stref, w których poziom substancji w powietrzu przekracza poziom dopuszczalny powiększony o margines tolerancji. Organy opiniujące są zobowiązane do wydania opinii w terminie miesiąca, a jej niewydanie $\mathrm{w}$ terminie oznacza akceptację projektu Uchwały w sprawie programu ochrony powietrza. Sejmik województwa uchwala program ochrony powietrza w terminie 18 miesięcy od dnia otrzymania wyników oceny poziomów substancji w powietrzu i klasyfikacji stref.

Na podstawie art. 84 ust. 7 u.p.o.ś. dla stref, w których został przekroczony poziom dopuszczalny albo poziom docelo- 
wy więcej niż jednej substancji w powietrzu, można sporządzić wspólny program ochrony powietrza dotyczący tych substancji. Z kolei jeżeli przyczyny wywołujące przekroczenia dopuszczalnych lub docelowych poziomów substancji w powietrzu występują na terenie innego województwa niż zlokalizowane są strefy, właściwe zarządy województw współdziałają przy sporządzaniu programów ochrony powietrza, w zakresie wymiany informacji o ewentualnych źródłach przekroczeń poziomów substancji w powietrzu oraz przykładowych działaniach mających na celu ich ograniczenie.

Opracowany przez zarząd województwa projekt programu ochrony powietrza powinien uwzględniać cele zawarte $\mathrm{w}$ innych dokumentach planistycznych i strategicznych, w tym w krajowym programie ochrony powietrza, wojewódzkich programach ochrony środowiska, regionalnych programach operacyjnych i koncepcji przestrzennego zagospodarowania kraju.

Ustawa określa również obowiązek aktualizacji programów ochrony powietrza. W przypadku stref, dla których programy ochrony powietrza zostały uchwalone, a standardy jakości powietrza są przekraczane, zarząd województwa jest obowiązany opracować projekt aktualizacji programu w terminie 3 lat od dnia wejścia w życie Uchwały sejmiku województwa w sprawie programu ochrony powietrza, określając w nim działania ochronne dla grup ludności wrażliwych na przekroczenie, obejmujących w szczególności osoby starsze i dzieci. Również po określeniu krajowego celu redukcji narażenia zarząd województwa jest obowiązany opracować projekt aktualizacji programu ochrony powietrza, określając dodatkowe działania mające na celu osiągnięcie krajowego celu redukcji narażenia.

Określenie szczegółowych wymagań, jakim powinny odpowiadać programy ochrony powietrza oraz plany działań krótkoterminowych, zostało delegowane do Rozporządzenia Ministra Środowiska z dnia 11 września 2012 r. w sprawie programów ochrony powietrza oraz planów działań krótkoterminowych ${ }^{45}$, które określa formę sporządzania i niezbędne części składowe programów ochrony powietrza oraz planów działań

45 Dz.U. z 2012 r., poz. 1028. 
krótkoterminowych, a także zakres zagadnień, które powinny zostać określone i ocenione $\mathrm{w}$ tych programach i planach, biorąc pod uwagę cele tych programów i planów oraz konieczność zapewnienia ochrony zdrowia ludzi i ochrony środowiska. W literaturze podnosi się wątpliwości co do konstytucyjności rozwiązania polegającego na unormowaniu przedmiotu aktu prawa miejscowego $\mathrm{w}$ akcie rangi podustawowej, jakim jest rozporządzenie. Należy jednak zauważyć, że wskazane rozporządzenie nie reguluje materii zastrzeżonej dla uregulowania ustawowego w zakresie określania zadań i kompetencji samorządu terytorialnego. Skupia się ono bowiem na zagadnieniach technicznych, takich jak forma sporządzania programu czy jego niezbędne części składowe, stanowiąc w tym ostatnim zakresie jedynie uszczegółowienie wymagań art. 84 ust. 2-3 u.p.o.ś. ${ }^{46}$

W orzecznictwie sądów administracyjnych problematyka programów naprawczych pojawia się zasadniczo w dwóch kontekstach. Pierwszy dotyczy zarzutu braku spełnienia wymogów generalności i abstrakcyjności norm prawnych zawartych w uchwałach sejmików podejmowanych na podstawie art. 84 ust. 1, w związku z art. 91 ust. 3 u.p.o.ś. W uzasadnieniu Wyroku z dnia 19 sierpnia 2010 r. ${ }^{47}$ Naczelny Sąd Administracyjny wskazał, że indywidualny i konkretny charakter obowiązku realizacji działań nałożony na prezydenta miasta Kędzierzyn-Koźle w Programie ochrony powietrza dla powiatu Kędzierzyńsko-Kozielskiego (stanowiącym załącznik do zaskarżonej uchwały) narusza podstawową cechę przepisów prawa miejscowego stanowiącą, że normy prawa miejscowego powinny być skierowane do nieokreślonego kręgu osób: „wprowadzenie do zaskarżonej Uchwały »Programu ochrony powietrza« zapisu odnoszącego się bezpośrednio i jedynie do Gminy Kędzierzyn-Koźle i zobowiązującego ten podmiot do likwidacji określonego sposobu ogrzewania na terenie wskazanych jednostek bilansowych nie spełnia wymogu abstrakcyjności i generalnego charakteru normy prawa miejscowego. Norma tak określona uległaby bowiem skonsumowaniu po spełnieniu zawartych w niej obowiąz-

47 Sygn. II OSK 1159/10. 
ków". Podobnie w Wyroku z dnia 7 października 2014 roku ${ }^{48}$ Naczelny Sąd Administracyjny stwierdził, że wprowadzenie do zaskarżonej uchwały normy o charakterze indywidualnym i konkretnym, odnoszącej się bezpośrednio do Prezydenta Miasta Poznania i zobowiązującej ten podmiot do obniżenia emisji $\mathrm{z}$ indywidualnych systemów grzewczych w wyniku eliminacji niskosprawnych urządzeń na paliwa stałe, nie spełnia wymogu abstrakcyjności i generalnego charakteru prawa miejscowego: „przyjmuje się, iż akt prawa miejscowego to akt normatywny, generalny i abstrakcyjny. Normatywny charakter aktu oznacza, że zawiera on wypowiedzi wyznaczające adresatom pewien sposób zachowania się, przybierający postać nakazu, zakazu lub uprawnienia. Charakter generalny oznacza natomiast, że normy zawarte $\mathrm{w}$ akcie definiują adresata poprzez wskazanie cech, a nie poprzez ich wymienienie z nazwy. Abstrakcyjność normy wyraża się w tym, że nakazywane, zakazywane lub dozwolone zachowanie ma mieć miejsce $\mathrm{w}$ pewnych, $\mathrm{z}$ reguły powtarzalnych, okolicznościach, nie zaś w jednej konkretnej sytuacji. Akty muszą więc dotyczyć zachowań powtarzalnych, nie mogą konsumować się przez jednorazowe zastosowanie po spełnieniu zawartych w nich obowiązków".

Drugim zarzutem jest nakładanie, na poszczególnych adresatów programów naprawczych, obowiązków niemożliwych przez nich do wykonania. Słusznie zauważa Naczelny Sąd Administracyjny we wspomnianym Wyroku z dnia 19 sierpnia 2010 roku, że sejmik województwa nie może w programie naprawczym zobowiązać organów gminy do egzekwowania obowiązków, co do których nie posiadają one kompetencji do ich nakładania: „gmina nie dysponuje uprawnieniami pozwalającymi na skuteczne nakazanie mieszkańcom zaprzestania ogrzewania należących do nich budynków przy pomocy pieców na paliwo stałe. Nie może również dostosować się do normy nakładającej na nią obowiązek wprowadzenia pasa zieleni na terenach nie stanowiących jej własności. Mogłaby tego dokonać jedynie w miejscowym planie zagospodarowania przestrzennego". Jest to również sprzeczne z zasadą braku wzajemnego podporząd-

${ }^{48}$ Sygn. II OSK 846/14. 
kowania poszczególnych szczebli samorządu terytorialnego. W ślad za tym orzeczeniem NSA - w cytowanym już Orzeczeniu z dnia 7 października 2014 roku - potwierdza, że prawo miejscowe nie może zawierać norm niemożliwych do wykonania: „organ wykonawczy gminy nie dysponuje uprawnieniami pozwalającymi na skuteczne nakazanie mieszkańcom wskazanych obszarów, zaprzestania ogrzewania budynków przy pomocy pieców na paliwo stałe, czy też utworzenia systemu zachęt finansowych do wymiany nieefektywnych urządzeń grzewczych, gdyż w istocie wykracza to poza kompetencje organów wykonawczych gmin".

\subsection{PLAN DZIAŁAŃ KRÓTKOTERMINOWYCH}

Artykuł 92 u.p.o.ś. stanowi implementację art. 94 Dyrektywy CAFE regulującego kwestie dotyczące sporządzania planów określających krótkoterminowe działania, podejmowane w celu ograniczenia zagrożenia lub skrócenia czasu występowania przekroczenia jednego lub kilku progów alarmowych albo wartości dopuszczalnych lub docelowych.

Plan działań krótkoterminowych również zalicza się do programów naprawczych $\mathrm{w}$ rozumieniu art. 84 u.p.o.ś., gdyż jednym z jego celów może być ograniczenie skutków i czasu trwania już zaistniałych przekroczeń. Świadczy o tym również art. 91 ust. 3a u.p.o.ś., zgodnie z którym plan działań krótkoterminowych stanowi integralną część programu ochrony powietrza lub jego aktualizacji dla stref, w których przekraczane są poziomy dopuszczalne substancji. Jednocześnie plan działań krótkoterminowych ma charakter zapobiegawczy, gdyż właściwe organy mogą podjąć działania już w chwili powstania ryzyka występowania przekroczeń dopuszczalnych, alarmowych lub docelowych poziomów substancji w powietrzu w danej strefie w celu zmniejszenia tego ryzyka.

Artykuł 92 ust. 1 u.p.o.ś. stanowi podstawę do przyjęcia przez sejmik województwa uchwały będącej aktem prawa miejscowego i określa procedurę jej uchwalenia, która - inicjowana przez zarząd województwa - stanowi w głównej mierze powie2/2015 lenie przepisów dotyczących programów ochrony powietrza. 
W kontekście doraźnego charakteru planu krótkoterminowego wątpliwości budzi zwłaszcza czas, który ustawodawca daje lokalnym organom na podjęcie określonych ustawą działań: w przypadku zarządu województwa 15, a w przypadku sejmiku województwa 18 miesięcy od dnia otrzymania informacji o ryzyku wystąpienia w danej strefie przekroczenia poziomu alarmowego, dopuszczalnego lub docelowego substancji w powietrzu od wojewódzkiego inspektora ochrony środowiska.

Plan działań krótkoterminowych powinien w szczególności zawierać listę podmiotów korzystających ze środowiska, obowiązanych do ograniczenia lub zaprzestania wprowadzania z instalacji gazów lub pyłów do powietrza, sposób organizacji i ograniczeń lub zakazu ruchu pojazdów i innych urządzeń napędzanych silnikami spalinowymi, sposób metodę postępowania organów, instytucji i podmiotów korzystających ze środowiska oraz zachowania się obywateli w przypadku wystąpienia przekroczeń oraz określenie trybu i sposobu ogłaszania o zaistnieniu przekroczeń.

Z analizy treści powyższego zestawienia uprawnień sejmiku wynika, że podejmowana przez ten organ uchwała może w sposób istotny ingerować w prawa i wolności jednostki. W tym kontekście wątpliwości budzi sposób ujęcia zakresu regulacji w upoważnieniu ustawowym, tj. przy użyciu zwrotu „w szczególności", podczas gdy uprawnienia organu wkraczające w sferę wolności i praw jednostki powinny stanowić katalog zamknięty. Należy jednak podkreślić, że - ze względu na swój cel - rozwiązania przyjęte $\mathrm{w}$ uchwale sejmiku powinny mieć charakter jedynie doraźny, zapobiegawczy i tymczasowy, a ostateczne granice działania wyznacza sejmikowi art. 84 u.p.o.ś. ${ }^{49}$

49 B. Rakoczy, op. cit., s. 147. 


\subsection{UCHWAŁA W CELU ZAPOBIEŻENIA NEGATYWNEMU ODDZIAŁYWANIU NA ŚRODOWISKO LUB NA ZABYTKI}

Szczególne uprawnienie sejmiku określa art. 96 u.p.o.ś., na podstawie którego może on podjąć uchwałę mającą na celu zapobieżenie negatywnemu oddziaływaniu na środowisko lub zabytki. Uchwała sejmiku podejmowana na podstawie art. 96 u.p.o.ś. nie jest wyraźnie wskazana przez ustawodawcę jako akt prawa miejscowego. Jednak analiza treści samego upoważnienia, prowadzi do wniosku, że uchwała taka zawiera przepisy o charakterze powszechnie obowiązującym.

Na podstawie art. 96 u.p.o.ś. sejmik może dla terenu województwa lub jego części określić 1) rodzaje lub jakość paliw dopuszczonych do stosowania; 2) sposób realizacji i 3) kontroli tego obowiązku. Określenie rodzajów lub jakości paliw dopuszczonych do stosowania jest sformułowaniem nakazu stosowania właśnie tych rodzajów paliw lub takiej jakości paliw. Przepis art. 96 u.p.o.ś. zawiera tutaj alternatywę: określa się albo rodzaje paliw dopuszczonych do stosowania, albo jakość paliw dopuszczonych do stosowania, tzn. musi się pojawić któraś z tych regulacji. Wydaje się, że dopuszczalny, z punktu widzenia celowościowej wykładni tego przepisu, jest także charakter mieszany, tzn. dla określonych paliw wskazuje się na rodzaje, a dla innych na jakośćc ${ }^{0}$.

W kontekście ograniczenia przedmiotowego zakresu uchwały sejmiku należy wskazać na uregulowania Ustawy z dnia 25 sierpnia 2006 r. o systemie monitorowania i kontrolowania jakości paliw ${ }^{51}$, która dokonuje implementacji Dyrektywy Parlamentu Europejskiego i Rady nr 98/70/WE z dnia 13 października 1998 r., odnoszącej się do jakości benzyny i olejów napędowych oraz zmieniającej Dyrektywę Rady nr 93/12/EWG ${ }^{52}$. Zakres obowiązywania ustawy z 2006 r. został określony w jej art. 1 ust. 1, zgodnie $\mathrm{z}$ którym $\mathrm{w}$ celu ograniczania negatyw-

50 Z. Bukowski, op. cit., s. 53.

51 Dz.U. z 2006 r., poz. 1200 ze zm., dalej cyt.: ustawa z 2006 r.

52 Dz. Urz. UE L 350 z 28.12.1998, s. 58 ze zm., dalej cyt.: Dyrektywa nr 98/70/WE. 
nych skutków oddziaływania paliw na środowisko oraz zdrowie ludzi, określa ona m.in. zasady organizacji i działania systemu monitorowania i kontrolowania jakości paliw przeznaczonych do stosowania: 1) w pojazdach, w tym: ciągnikach rolniczych, maszynach nieporuszających się po drogach, a także rekreacyjnych jednostkach pływających, jeżeli nie znajdują się na wodach morskich; 2) w instalacjach energetycznego spalania oraz w statkach żeglugi śródlądowej, jeżeli nie znajdują się na wodach morskich oraz 3) przez rolników na własny użytek. Artykuł 1 ust. 2 ustawy z 2006 r. stanowi także, iż określa ona zasady kontrolowania jakości paliw stałych.

Powyższe oznacza, że - w zakresie unormowanym przez ustawę z 2006 r. - sejmik województwa nie może korzystać z kompetencji do podjęcia uchwały, mimo teoretycznych możliwości przyznanych mu w art. 96 u.p.o.ś., gdyż w ten sposób akt prawa miejscowego, jako hierarchicznie niższy, ingerowałby w materię będącą przedmiotem regulacji ustawowej. Znajduje to potwierdzenie $\mathrm{w}$ doktrynie ${ }^{53} \mathrm{i} \mathrm{w}$ orzecznictwie, np. w Wyroku Naczelnego Sądu Administracyjnego z dnia 28 stycznia 2010 r., w którym skład orzekający wskazuje, że: „organ władzy wykonujący kompetencję prawodawczą zawartą w upoważnieniu ustawowym jest obowiązany działać ściśle w granicach tego upoważnienia. Nie jest upoważniony ani do regulowania tego, co zostało już ustawowo uregulowane, ani też do wychodzenia poza zakres upoważnienia ustawowego"54.

Niektórzy autorzy podnoszą również ${ }^{55}$, że korzystanie przez sejmik z kompetencji przyznawanej mu przez art. 96 u.p.o.ś. powinno zostać zakwalifikowane jako naruszenie Dyrektywy nr 98/70/WE. W art. 6 na zasadzie odstępstwa zezwala ona państwom członkowskim na wprowadzenie surowszych niż określone dyrektywą wymagań jakościowych w odniesieniu do paliw spalinowych na określonym terytorium państw członkowskich, przy czym państwo członkowskie, które chce skorzystać z takiego odstępstwa musi udowodnić Komisji, że nie narusza

4 Sygn. I OSK 1518/09.

55 M. Pchałek, op. cit., s. 374. 
w ten sposób zasady proporcjonalności, ani swobodnego przepływu osób i towarów. Rzeczywiście, wydaje się, że zakres kompetencji przyznany sejmikowi w art. 96 u.p.o.ś. jest szerszy niż ten, w który Dyrektywa nr 98/70/WE wyposaża organy państw członkowskich. Ponadto procedura podejmowania uchwały sejmiku na podstawie art. 96 u.p.o.ś. może naruszać wskazany w art. 6 ust. 2-8 Dyrektywy nr 98/70/WE tryb notyfikacji do Komisji regulacji krajowych zawierających surowsze specyfikacje środowiskowe.

Uregulowanie z art. 96 u.p.o.ś. należy do kontrowersyjnych i jest krytykowane w literaturze jako zbyt ogólnie sformułowane. Niewątpliwie bowiem określenie rodzajów lub jakości paliw dopuszczonych do stosowania, realizowanie takiego obowiązku i kontrola jest ingerencją $\mathrm{w}$ sferę praw i wolności jednostki, w tym w swobodę prowadzenia działalności gospodarczej. Co za tym idzie, zgodnie z zasadą proporcjonalności wyrażoną w art. 31 ust. 3 Konstytucji, ustawodawca powinien wprowadzić ograniczenia, np. czasowe i merytoryczne, dla stosowania nakazów wprowadzanych uchwałą sejmiku, jak również co do określenia sposobu realizacji, rodzaju i zakresu kontroli ${ }^{56}$.

W praktyce orzeczniczej głośnym echem odbiła się sprawa tzw. „uchwały antysmogowej” uchwalonej przez sejmik województwa małopolskiego w dniu 25 listopada 2013 r. ${ }^{57}$ Następnie Wojewódzki Sąd Administracyjny w Krakowie nieprawomocnym Wyrokiem z dnia 22 sierpnia $2014 \mathrm{r}^{58}$ stwierdził jej nieważność. Wyrok został zaskarżony, a w chwili dostarczenia niniejszego artykułu do druku sprawa nie została jeszcze rozpoznana przez Naczelny Sąd Administracyjny. Obszerne uzasadnienie do wyroku zawiera rozbudowaną wykładnię przepisów zarówno art. 96 u.p.o.ś., jak i zaskarżonej uchwały sejmiku. Stwierdzając nieważność uchwały, Wojewódzki Sąd Administracyjny w Kra-

56 B. Rakoczy, op. cit., s. 156.

57 Uchwała nr XLIV/703/13 Sejmiku Województwa Małopolskiego z dnia 25 listopada 2013 r. w sprawie określenia rodzajów paliw dopuszczonych do stosowania na obszarze Gminy Miejskiej Kraków, http://bip.malopolska.pl/ umwm/Article/get/id,833236.html [dostęp: 03.03.2015 r.]

58 Sygn. II SA/Kr 490/14. 
kowie zarzucił m.in., że nie określa ona wprost adresata, „zaś aby konkretny podmiot mógł ocenić czy winien stosować się do nakazu z $\S 1$ musi dokonać skomplikowanej wykładni $\S 2$, w ramach której należy uwzględniać nie tylko przepisy ustaw, ale licznych rozporządzeń wykonawczych". Sąd stwierdził również, że uchwała jest nieczytelna i utrudnione jest określenie wzoru powinnego postępowania: „naruszeniem Konstytucji RP jest stanowienie przepisów niejasnych, wieloznacznych, niepozwalających jednostce przewidzieć konsekwencji prawnych jej zachowań (tak: TK w Wyroku z dnia 22 maja 2002 r. K 6/02, OTK ZU 2002, nr 3/A/2002, poz. 33, s. 448). Takie właśnie negatywne cechy charakteryzują zaskarżoną uchwałę, niezależnie od naruszenia zasad techniki prawodawczej. [...] Prawodawca powinien tak kształtować normy prawne, aby w sposób jasny i precyzyjny określały adresata i wzorzec powinnego postępowania zwłaszcza wówczas, gdy za naruszenie tego wzorca grożą sankcje karne lub innego rodzaju konsekwencje mogące wkraczać w sferę praw i wolności jednostki". Ponadto skład orzekający stwierdził, że zaskarżona uchwała narusza art. 96 u.p.o.ś., gdyż wyłączyła ona spod swojego działania instalacje wymagające pozwolenia zintegrowanego, podczas gdy analizowany przepis zezwala na określanie rodzajów lub jakości paliw dopuszczonych do stosowania jedynie przy zastosowaniu kryterium terytorialnego: „uzależnianie określania rodzajów lub jakości paliw dopuszczonych do stosowania dla terenu województwa bądź jego części od celu stosowania paliw jest niedopuszczalne i oznacza wykroczenie poza granice upoważnienia ustawowego".

\section{ZAKOŃCZENIE}

Organy samorządu terytorialnego stanowiące prawo miejscowe powszechnie obowiązujące na obszarze działania tych organów, w tym uchwały w zakresie ochrony powietrza, powinny w tym samym stopniu co ustawodawca uwzględniać wymogi tzw. przyzwoitej legislacji. Jednak obserwuje się, iż w praktyce 
organy te przyjmują wadliwe uchwały, co skutkuje stwierdzeniem ich nieważności przez sądy administracyjne. W przypadku programów naprawczych wydaje się, że wadliwość tych aktów może częściowo wynikać z szerszego problemu dotyczącego polskiego prawa ochrony środowiska, a mianowicie nakładania na podmioty korzystające ze środowiska obowiązków o konkretnym charakterze nie w drodze decyzji administracyjnej, ale właśnie w formie aktu normatywnego. Wydaje się, że - zamiast wyposażania kolejnych organów w kompetencje do stanowienia prawa - właściwszy dla rozwiązania danego problemu środowiskowego byłby model stosowania prawa ${ }^{59}$, wymagałoby to jednak głębokich zmian ustawowych. Ponadto należałoby się zastanowić nad umiejscowieniem kompetencji prawotwórczych w łonie organu posiadającego jednocześnie wiedzę i zaplecze specjalistyczne. Taka reforma instytucjonalna mogłaby przyczynić się do znaczącej poprawy funkcjonowania administracji publicznej w tym zakresie.

Z kolei odnośnie regulacji art. 96 u.p.o.ś. wywołuje ona wątpliwości ze względu na niejednoznacznie określony zakres kompetencji sejmiku i możliwość zbyt daleko idącego wkraczania w konstytucyjną sferę wolności i praw jednostki. Wymagana będzie tu interwencja ustawodawcy, tym bardziej, że analizowany przepis potencjalnie narusza prawo Unii Europejskiej.

\section{BIBLIOGRAFIA}

Adamiak B., Nieważność aktu prawa miejscowego a wadliwość decyzji administracyjnej, „Państwo i Prawo” 2002, nr 9.

Bukowski Z., Jędrzejewski T., Rączka P., Ustrój samorządu terytorialnego, Toruń 2011.

Bukowski Z., Możliwości prawne wprowadzenia zakazu spalania określonych paliw statych na terenie gminy, „Studia z zakresu prawa, administracji i zarządzania UKW" 2012, t. 1.

59 B. Rakoczy, Postępowanie $w$ sprawie ustanowienia obszaru ograniczonego użytkowania w prawie polskim, „Prawo i Środowisko” 2013, nr 2, s. 61-68. 
Chojnacka I., Przesłanki legalności aktu prawa miejscowego $w$ orzecznictwie sądów administracyjnych, „Zeszyty Naukowe Sądownictwa Administracyjnego" 2012, nr 4.

Ciapała J., Powszechnie obowiązujące akty prawa miejscowego, „Przegląd Sejmowy" 2000, nr 3.

Dąbek D., Prawo miejscowe, Kraków-Bydgoszcz 2007.

Dobosz P., Quasi-akty prawa miejscowego, w: Problemy prawne działalności samorządu terytorialnego, red. S. Dolata, Opole 2002.

Dobrowolski G., Propozycja reformy instytucjonalnej ochrony środowiska, w: Administracja publiczna - człowiek a ochrona środowiska. Zagadnienia społeczno-prawne, red. M. Górski, J. Bucińska, M. Niedziółka, R. Stec, D. Strus, Warszawa 2011.

Dolnicki B., Akty prawa miejscowego samorzadu terytorialnego, „Samorząd Terytorialny" 2004, nr 5.

Dudziak S., Akty prawa miejscowego stanowione przez samorzad terytorialny - kryteria kwalifikacji, wymogi w zakresie prawidłowego stanowienia oraz konsekwencje prawne ich naruszenia, „Samorząd Terytorialny" 2012, nr 3.

Federczyk W., Majchrzak B., Akt normatywny $w$ orzecznictwie TrybunaŁu Konstytucyjnego. Problemy na tle aktów organów administracji, w: Źródła prawa administracyjnego a ochrona wolności i praw obywateli, red. M. Błachucki, T. Górzyńska, Warszawa 2014.

Frankiewicz E., Szewczyk M., Generalny akt administracyjny, „Państwo i Prawo" 2003, nr 12.

Górski M., Prawo ochrony środowiska, red. M. Górski, Warszawa 2014. Gruszecki K., Prawo ochrony środowiska. Komentarz, Warszawa 2011. Jaroszyński T., Zasady techniki prawodawczej a akty prawa miejscowego. Wybrane problemy $w$ świetle orzecznictwa Naczelnego Sądu Administracyjnego, „Kwartalnik Prawa Publicznego” 2013, nr 1.

Kamiński M., Koncepcja nieważności aktów prawa miejscowego jednostek samorzadu terytorialnego $w$ polskich ustawach samorzadowych, „Samorząd Terytorialny” 2007, nr 5.

Karpus K., Implementation of directive 2008/50/EC of 21 May 2008 on Ambient Air Quality and Cleaner Air for Europe in Polish environmental law, „Polish Yearbook of Environmental Law” 2012.

Korzeniowski P., Model prawny ochrony powietrza $w$ ustawie - Prawo ochrony środowiska, „Prawo i Środowisko” 2014, nr 1.

Kotulski M., Akty prawa miejscowego w świetle uregulowań ustrojowych, „Kwartalnik Prawa Publicznego” 2001, nr 1.

Morawski L., Wstęp do prawoznawstwa, Toruń 1997.

Morawski L., Wstęp do prawoznawstwa, Toruń 2014. 
Pchałek M., w: M. Górski, M. Pchałek, W. Radecki, J. Jerzmański, M. Bar, S. Urban, J. Jendrośka, Prawo ochrony środowiska. Komentarz, Warszawa 2014.

Rakoczy B., w: Z. Bukowski, E. K. Czech, K. Karpus, B. Rakoczy, Prawo ochrony środowiska. Komentarz, Warszawa 2013.

Rakoczy B., Postępowanie w sprawie ustanowienia obszaru ograniczonego użytkowania $w$ prawie polskim, „Prawo i Środowisko” 2013, nr 2.

Rotko J., Komentarze do ustawy - Prawo ochrony środowiska, Wrocław 2002.

Skrzydło W., Konstytucja Rzeczypospolitej Polskiej. Komentarz, Warszawa 2013.

Stahl M., Zagadnienia proceduralne sq̨dowej kontroli aktów prawa miejscowego, "Zeszyty Naukowe Sądownictwa Administracyjnego" 2013, nr 3.

Stawecki T., Winczorek P., Wstęp do prawoznawstwa, Warszawa 2003.

Szewc T., Problem kwalifikacji aktów prawa miejscowego, „Przegląd Sejmowy" 2006, nr 3.

Wiktorowska A., Prawne determinanty samodzielności gminy (zagadnienia administracyjnoprawne), Warszawa 2002.

Ziembiński Z., Teoria prawa, Warszawa-Poznań 1977.

Zimmermann J., Prawo administracyjne, Warszawa 2008.

Kontakt - e-mail:

mgmalecka@hotmail.com 